\title{
IDENTIFICATION AND MICROPROPAGATION OF VIRUS-FREE BLACK PEPPER GENOTYPES (Piper nigrum $L$.)
}

\section{Gleyce Kelly de Sousa Ramos ${ }^{(1)}$, Oriel Filgueira de Lemos ${ }^{(2)}$, Elisa Ferreira Moura Cunha ${ }^{(2)}$, Alessandra de Jesus Boari(2), Danielle Pereira Mendonça ${ }^{(1)}$, Lana Roberta Reis dos Santos ${ }^{(1)}$, Simone de Miranda Rodrigues ${ }^{(2)}$, Ilmarina Campos de Menezes ${ }^{(3)}$}

\author{
(1) Discente da Universidade Federal Rural da Amazônia, Avenida Presidente Tancredo Neves 2501, caixa postal 1917, CEP: 66077-530 \\ Belém, PA, Brasil. \\ (2) Pesquisador da Embrapa Amazônia Oriental, Pavilhão de Pesquisa, Travessa Dr. Enéas Pinheiro, S/N, Caixa Postal 48, CEP: 66095- \\ 903 Belém, PA, Brasil. \\ (3) Analista da Embrapa Amazônia Oriental, Pavilhão de Pesquisa, Travessa Dr. Enéas Pinheiro, S/N, Caixa Postal 48, CEP: 66095-903 \\ Belém, PA, Brasil.
}

*Autor para correspondência: Gleyce Kelly de Sousa Ramos; e-mail: gleyceramos17@yahoo.com.br.

\begin{abstract}
Virus infections are a major constraint for black pepper cultivation (Piper nigrum L.), a vegetatively propagated crop; therefore, the in vitro selection of virus- free plants is an alternative to reestablish phytosanitary quality of pepper culture. The aim of this study was to select and micropropagate PYMoV virus-free pepper plants. 'Apra', 'Bragantina', 'Cingapura', 'Clonada', hybrids and 'Kottanadan' genotypes were used in the indexing process. From these, 'Cingapura', 'Clonada', hybrids and 'Kottanadan' were virus free, and only 'Cingapura' and 'Clonada' were selected for micropropagation. In the multiplication phase, 'Cingapura' genotype showed higher multiplication rate in relation to 'Clonada' in in vitro rooting and in acclimatization, response was similar in both genotypes. It was possible to identify virus-free genotypes of commercial interest, selecting them for micropropagation, and in this stage, influence of genotype is of great importance.
\end{abstract}

KEYWORDS: Badnavirus, tissue culture, plant indexing, PYMoV.

\section{IDENTIFICAÇÃO E MICROPROPAGAÇÃO DE GENÓTIPOS DE PIMENTEIRA-DO-REINO (Piper nigrum L.) LIVRES DE VÍRUS}

RESUMO: As infecções por vírus são um dos principais obstáculos para o cultivo de pimenteira-do-reino, uma cultura propagada vegetativamente, por isso, a seleção de plantas livres de vírus é uma alternativa para reestabelecer a pipericultura com qualidade fitossanitária. Objetivou-se identificar, selecionar genótipos e micropropagar de pimenteira-do-reino livre do vírus PYMoV. Na indexação foram utilizados os genótipos Apra, Bragantina, Cingapura, Clonada, híbridos e Kottanadan. Destes Cingapura, Clonada, híbridos e Kottanadan estavam livre de vírus, e foram selecionados para a micropropagação apenas Cingapura e Clonada. Na fase de multiplicação Cingapura mostrou taxa de multiplicação superior a Clonada, no enraizamento in vitro e na aclimatização a resposta foram semelhantes em ambos os genótipos. Foi possível identificar genótipos de interesse comercial livre de vírus, selecionando-os para a micropropagação, nesta etapa o genótipo tem influência.

PALAVRAS CHAVE: Badnavirus, cultura de tecidos, indexação de plantas, PYMoV.

\section{INTRODUCTION}

Black pepper (Piper nigrum L.) is a climbing species that belongs to family Piperaceae, one of the main spices of economic interest cultivated in Brazil and other countries. Brazil is the main non-Asian producer and the states of Pará, Espírito Santo and Bahia account for more than $99 \%$ of national production (Lourinho et

\section{al., 2014; IBGE, 2019).}

It is a crop cultivated mainly by small producers, generating income for farmers, avoiding rural exodus and each ton of black pepper harvested corresponds to a job in the field (Lemos et al., 2011). Price is an incentive to production, and the spice, in the national market, has already reached prices above $\mathrm{R} \$ 30,00$ 
I kg (Conab, 2018), but for production to compete in the international market, cultivation with phytosanitary quality is necessary.

Before beginning the vegetative propagation process, previous indexing of plants is necessary to select the healthy material to be used in the multiplication process. Virus infection is one of the obstacles to black pepper cultivation, and once infected, the propagating material becomes the main transmission route; inside the host cell, the viral nucleic acid must direct the cell machinery for the synthesis of new viral particles, causing the disease (Bhat et al., 2009; Bhat et al., 2018).

Cucumber mosaic virus (CMV) and Piper yellow mottle virus (PYMoV) have already been associated with black pepper diseases, causing black pepper mosaic and mottle, respectively (Bhat et al., 2018). PYMoV, the most widespread virus in Brazilian crops, belongs to genus Badnavirus (Family Caulimoviridae), being transmitted mainly by vegetative propagation, seeds, mealybugs and cultural treatments (Bhat et al., 2003; Duarte et al., 2000). It consists of bacilliform particles of $125 \mathrm{~nm} \times 30 \mathrm{~nm}$ in size, with double-stranded DNA of about 7.0kbp (Silva et al., 2002).

This virus has been reported in Asian countries such as India, Philippines, Malaysia, Sri Lanka and nonAsian countries such as Brazil. In all countries, it acts as an obstacle to the crop production system (Bhat et al., 2018; Duarte et al., 2000; Lockhart et al., 1997). PYMoV causes variable symptoms such as mottle and leaf distortion, bright chlorotic spots dispersed in the leaf or between ribs, shortened internodes and deficient spike filling, leading to reduced yield, and as a consequence economic loss (Duarte et al., 2000; Lockhart et al., 1997). Infected plants can be apparently healthy or exhibit symptoms that can vary from mild to severe, being influenced by biotic and abiotic factors (Bhat et al., 2018; Umadevi et al., 2016).

The application of biotechnological techniques is a viable alternative for mass propagation and cloning of crops of economic interest, with phytosanitary quality, as is the case with black pepper. To this end, it is possible to combine in vitro cultivation techniques to propagate them on a large scale, and techniques such as PCR, to perform virus indexing (Umadevi et al., 2015). Black pepper indexing is indicated both in symptomatic and asymptomatic plants (Bhat et al., 2009; Bhat et al., 2018)
Through plant indexing, it is possible to identify plants free of viruses (and / or other diseases) and, subsequently, select them for the plant propagation stage. The health of seedlings must be guaranteed during the entire propagation process in order to prevent the spread of the virus that reflects in reduced production. In the case of black pepper, the main means of crop propagation is vegetative, which can become a route of PYMoV transmission and responsible for the introduction of the pathogen in new planting areas if mother plants are infected; therefore, this culture demands virus-free mother plants (Bhat et al., 2018; Sasi et al., 2018).

Considering the difficulties of finding virus-free black pepper genotypes in the field, in vitro selection is an alternative to reestablish pepper culture with phytosanitary quality. For this, it is necessary to choose genotypes of commercial interest to pepper producers. Thus, the aim was to identify, select and micropropagate black pepper genotypes free from PYMoV virus.

\section{MATERIAL AND METHODS}

The work was conducted at the Laboratory of Genetic Resources and Plant Biotechnology and Laboratory of Phytopathology of "Embrapa Amazônia Oriental", Belém - PA, and included the indexing of plants established in vitro for the PYMoV virus; selection and cloning via micropropagation of two virus-free genotypes ('Cingapura' and 'Clonada') contemplating the behavior evaluation in the bud multiplication, rooting and acclimatization stages of plants.

\section{Indexing of black pepper genotypes}

Initially, five asymptomatic plants of 'Apra', 'Bragantina', 'Cingapura', 'Clonada', hybrids and 'Kottanadan' genotypes kept in vitro at the Active Germplasm Bank (AGB) of "Embrapa Amazônia Oriental" were indexed via PCR. Leaves, collected from the study genotypes, were submitted to RNA extraction based on the Gibbs and Mackenzie (1997) protocol with modifications.

For indexing, three pairs of primer specific for PYMoV were used: primers 1 and 2 (whose sequences have not been published and cannot be released). PCR reactions were performed in final volume of $25 \mu \mathrm{L}$, containing $2.5 \mu \mathrm{L}$ of reaction $10 \mathrm{X}$ buffer, 0.75 $\mu \mathrm{l}$ of $\mathrm{MgCl}_{2}(50 \mathrm{mM}) ; 0.25 \mu \mathrm{L}$ of dNTP $(2 \mathrm{mM}), 0.25$ 
$\mu \mathrm{L}$ of each oligonucleotide $(10 \mathrm{mM}), 3 \mu \mathrm{l}$ of nucleic acid ( $5 \mathrm{ng} / \mu \mathrm{L}$ ) and one unit of Taq DNA Polymerase, completing the volume with ultrapure $\mathrm{H}_{2} \mathrm{O}$. The thermal cycling conditions consisted of 30 denaturation cycles at $94^{\circ} \mathrm{C}$ for 1 minute, annealing at $49.5^{\circ} \mathrm{C}$ for 1 minute and extension at $72^{\circ} \mathrm{C}$ for 1 minute, followed by final extension at $72^{\circ} \mathrm{C}$ for 4 minutes.

Amplified products were analyzed on $0.8 \%$ agarose gel, stained in gelRed and visualized under UV light. After confirming the presence or not of viral DNA, plants were reindexed by three subcultures to confirm the phytosanitary quality of the cultivated material.

\section{In vitro multiplication, rooting and acclimatization}

The material used in this research is part of the active black pepper germplasm bank of "Embrapa Amazônia Oriental". For micropropagation, two genotypes ('Clonada' and 'Cingapura'), free from the PYMoV virus, were selected, of which stem apexes were used as source of explants. In the bud multiplication phase, explants $( \pm 1 \mathrm{~cm})$ were inoculated in culture medium composed of MS mineral salts (Murashige and Skoog, 1962) and Write vitamins, 3\% sucrose, $0.2 \%$ phytagel, supplemented with $0.2 \mathrm{mg} \mathrm{L}^{-1} \mathrm{IAA}$ (indolacetic acid) and $0.5 \mathrm{mg} \mathrm{L-1} \mathrm{BAP} \mathrm{(6-benzylaminapurine)} \mathrm{and}$ streptomycin, with $\mathrm{pH}$ adjusted to 5.8 in cylindrical glass flasks containing $40 \mathrm{~mL}$.

The design used was completely randomized with two treatments (genotypes) and five replicates, and each flask with five explants constituted one replicate. Five subcultures were performed and each occurred within eight weeks. The growing conditions in the growth room were controlled temperature (25 $\pm 3{ }^{\circ} \mathrm{C}$ ), $16 \mathrm{~h}$ photoperiod and 3,000 lux light intensity provided by fluorescent lamps. Evaluation considered the multiplication rate by subcultures and the average production of buds was generated in five subcultures.

After the fifth subculture, explants of 'Clonada' and 'Cingapura'genotypes were transferred to the rooting medium, in cylindrical glass flasks containing $40 \mathrm{~mL}$ of the basic MS culture medium with half the concentration of salts $(1 / 2 \mathrm{MS})$ with $3 \%$ sucrose , supplemented with $0.05 \mathrm{mg} \mathrm{L}^{-1}$ NAA (naphthalene acetic acid), pH adjusted to 5.8 ephytagel at $0.2 \%$.

After the eight weeks of the rooting period, the following were evaluated: number, length and diameter of roots; number of leaves; bud length; shoot dry mass and root dry mass. Measurements were performed with the aid of digital caliper (accuracy of $0.01 \mathrm{~mm}$ ). To determine the shoot dry mass and the root system, rooted buds were segmented and placed in oven at 60 ${ }^{\circ} \mathrm{C}$ for 72 hours and, after this period, with the aid of a precision scale, data were recorded. Fifteen plants were used for each genotype, with each plant representing a replicate.

Rooted buds of 'Clonada' and 'Cingapura' genotypes were subsequently transferred to 24-cell polypropylene plastic trays containing moistened vermiculite as substrate, each cell with two plants.

The plant material remained in greenhouse for four weeks, with intermittent nebulization every $10 \mathrm{~min}$. Nutrient solution with MS salts $(1 / 2 \mathrm{MS})$ was applied every 15 days. After this period, number, length and diameter of roots, bud length, number of leaves, shoot dry mass and root dry mass and survival rate were analyzed. For data collection, the same rooting procedures were adopted. Fifteen plants were used for each genotype, and each plant represented a replicate.

Data from micropropagation, multiplication, rooting and acclimatization phases were submitted to statistical analysis using the Assistat 7.7 beta software for analysis of variance and $t$ test of comparison of means at $5 \%$ probability level.

\section{RESULTS AND DISCUSSION}

Based on indexing, it was possible to identify and evaluate the phytosanitary quality of black pepper genotypes regarding PYMoV virus. Both primers used were efficient for the amplification of the specific PYMoV band. Two primers were used, as they are initial works in this line of research, so it is necessary to test various methodologies to prove the veracity of the information. Another relevant factor for the use of this primer was that those available in literature, in some cases, failed to detect the presence of the virus even in symptomatic black pepper materials belonging to the Active Germplasm Bank (AGB) of "Embrapa Amazônia Oriental" (Boari, 2008).

All plants of 'Apra' and 'Bragantina' genotypes were positive for the PYMoV virus, with fragment amplification of approximately $450 \mathrm{bp}$, which corresponds to PYMoV ORF I. 'Cingapura', 'Clonada', 'Kottanadan' and hybrids genotypes, in turn, were negative for PYMoV (Figure 1). 
Figure 1. Indexing of black pepper genotypes grown in vitro to detect PYMoV with primer ( $F$ and $R)$. $M$ - $1 \mathrm{~kb}$ ladder marker; 1 - positive control; 2 - negative control; 3 - $\mathrm{H}_{2} \mathrm{O}$; 4 - 'Cingapura'; 5 - 'Clonada'; 6 - hybrid ('Guajarina' x P. arboreum), 7 - hybrid ('Bragantina' x arboreum); 8 - hybrid ('Bento' x 'Guajarina'); 9 - 'Kotanadan'; 10 - 'Apra'; and 11 - 'Bragantina'. The PYMoV band is $450 \mathrm{bp}$

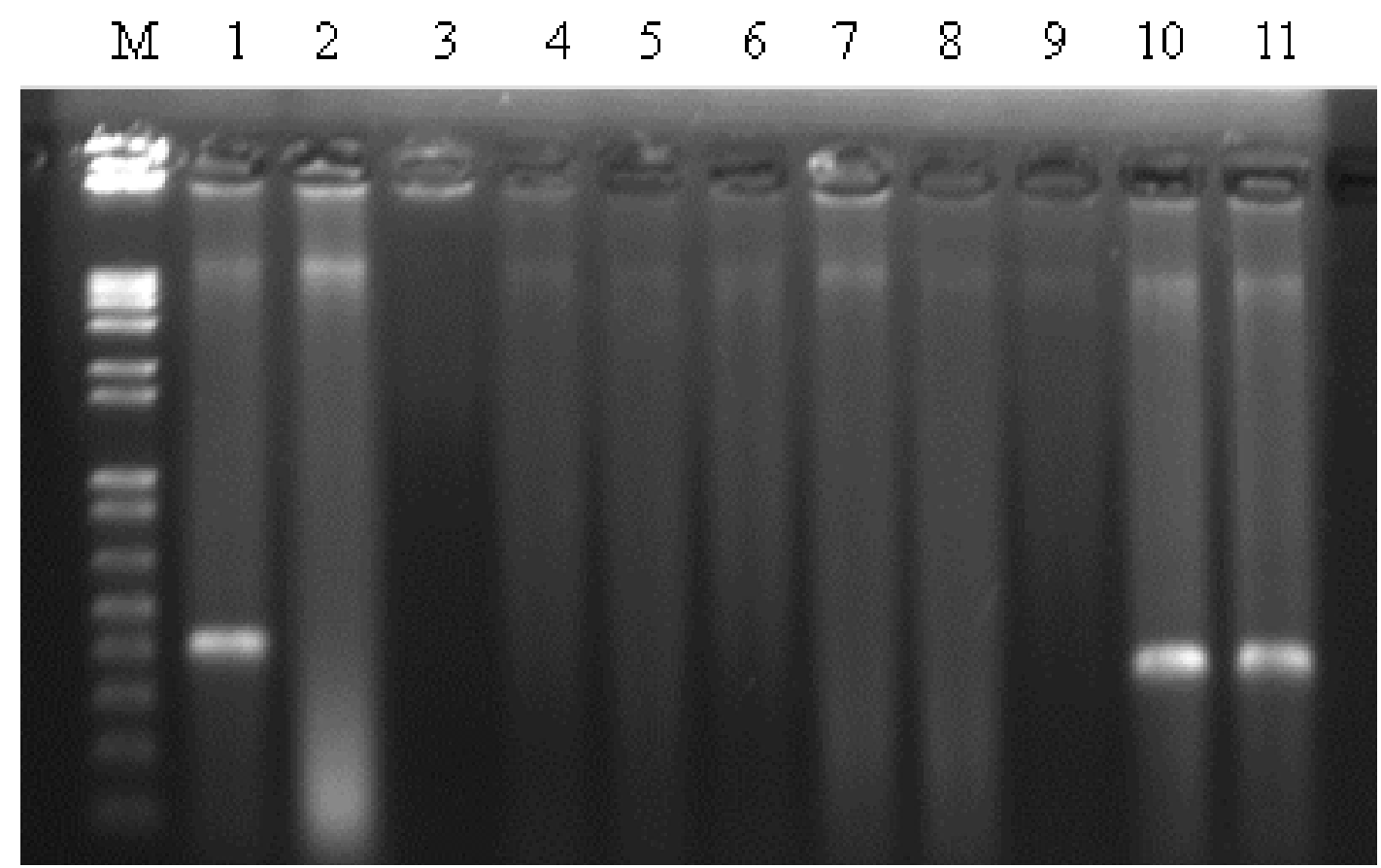

Indexing via PCR has been effective in detecting the PYMoV virus in major black pepper producing countries, especially when compared to serological tests such as ELISA (Enzyme-Linked Immunosorbent Assay) (Silva et al., 2002; Sasi et. Al., 2018). The correct identification of which virus infects the plant is necessary to support the development of phytosanitary defense strategies for black pepper crop, since more than one virus can infect the same plant (Miftakhurohmah et al., 2016). Pepper culture faces problems due to the occurrence of rampant viral diseases, and biotechnological tools can be used to solve this problem by identifying virus-free material via PCR, propagate on a large scale in a short time and space, in addition to ensuring phytosanitary quality throughout the process via tissue culture (Bhat et al. 2009; 2018).

Bhat et al. (2009) indexed 14 most popular black pepper genotypes grown in India and found that $82 \%$ of genotypes were infected with PyMoV virus. Umadevie collaborators (2015) found the presence of PYMoV virus in pepper plants regenerated in vitro. Even when evaluated genotypes were not symptomatic to the virus, it was possible to detect the presence of the virus in plants, and to select virus-free ones for crop propagation, as in this work, early virus detection is necessary for virus disease control (Bhat et al., 2018).

Among plants identified as free from the PYMoV virus, 'Cingapura' and 'Clonada' genotypes were selected as explant donors for micropropagation and seedling formation aiming at the implantation of black pepper mother plants. 'Cingapura' was the first genotype to be introduced in the state of Pará for commercial purposes and 'Clonada' - material to be launched as cultivar by "Embrapa Amazônia Oriental". Both genotypes are of interest to pepper producers due to their agronomic attributes.

'Cingapura' and 'Clonada' genotypes submitted to micropropagation passed through five subcultures during the bud multiplication phase. The ANOVA results showed that the multiplication rate of the 'Cingapura' genotype had superior responses in relation to 'Clonada' genotype, in all subcultures. The lowest multiplication rate occurred in the first subculture in both genotypes, varying from 1.3 to 2.2 new buds / explants. The highest multiplication rate of the 'Cingapura' genotype occurred in the fourth subculture, with average of 4.8 buds / explant, while the multiplication rate in the 'Clonada' genotype was higher in the fifth subculture, with 2.88 buds / explant (Table 1). 
Table 1. Multiplication rate of two black pepper genotypes in MS culture medium with $0.5 \mathrm{mg} . \mathrm{L}^{-1} \mathrm{BAP}$ and $0.2 \mathrm{mg}$ $\mathrm{L}^{-1}$ IAA in different subcultures.

\begin{tabular}{cccccc}
\hline \multirow{2}{*}{ Genotype } & \multicolumn{5}{c}{ Multiplication rate (subcultures) } \\
\cline { 2 - 6 } & 1st sub. & 2nd sub. & 3nd sub. & 4th sub. & 5th sub. \\
\hline 'Cingapura' & $2.2 \mathrm{a}$ & $3.96 \mathrm{a}$ & $3.52 \mathrm{a}$ & $4.80 \mathrm{a}$ & $3.96 \mathrm{a}$ \\
'Clonada' & $1.3 \mathrm{~b}$ & $2.52 \mathrm{~b}$ & $2.28 \mathrm{~b}$ & $2.68 \mathrm{~b}$ & $2.88 \mathrm{~b}$ \\
\hline CV (\%) & 27.14 & 20.14 & 32.74 & 32.62 & 34.18 \\
\hline
\end{tabular}

Means followed by the same letter do not differ statistically. The $\mathrm{F}$ test was applied at $5 \%$ probability level $(p<0.05)$

Culture micropropagation is influenced by several factors such as type of explant, genotype, culture medium, light and temperature (Castro et al., 2016). These results demonstrated that in vitro growth varied among the different genotypes under the different environmental conditions. Protocol for in vitro regeneration in the species has been developed to solve specific crop problems (Umadevi et al., 2015), an important step for the mass propagation of elite plants.
In the continuous multiplication phase, each genotype was represented by five initial explants from different plants. 'Cingapura' genotype had the highest average of buds from one explant in all subcultures. In the first subculture, the average per implant was 4 new buds, and in the fifth subculture, it reached average of 363 new buds / initial explant. 'Clonada' genotype, in turn, in the first subcultivation showed on average 2 new buds, and in the fifth subculture, it reached average of 89 buds / explant, which demonstrates the influence of the genotype in the bud multiplication phase (Figure 2).

Figure 2. Average of new buds obtained from initial explant obtained in the micropropagation multiplication phase in two black pepper genotypes during five subsequent subcultures for eight weeks per subculture.

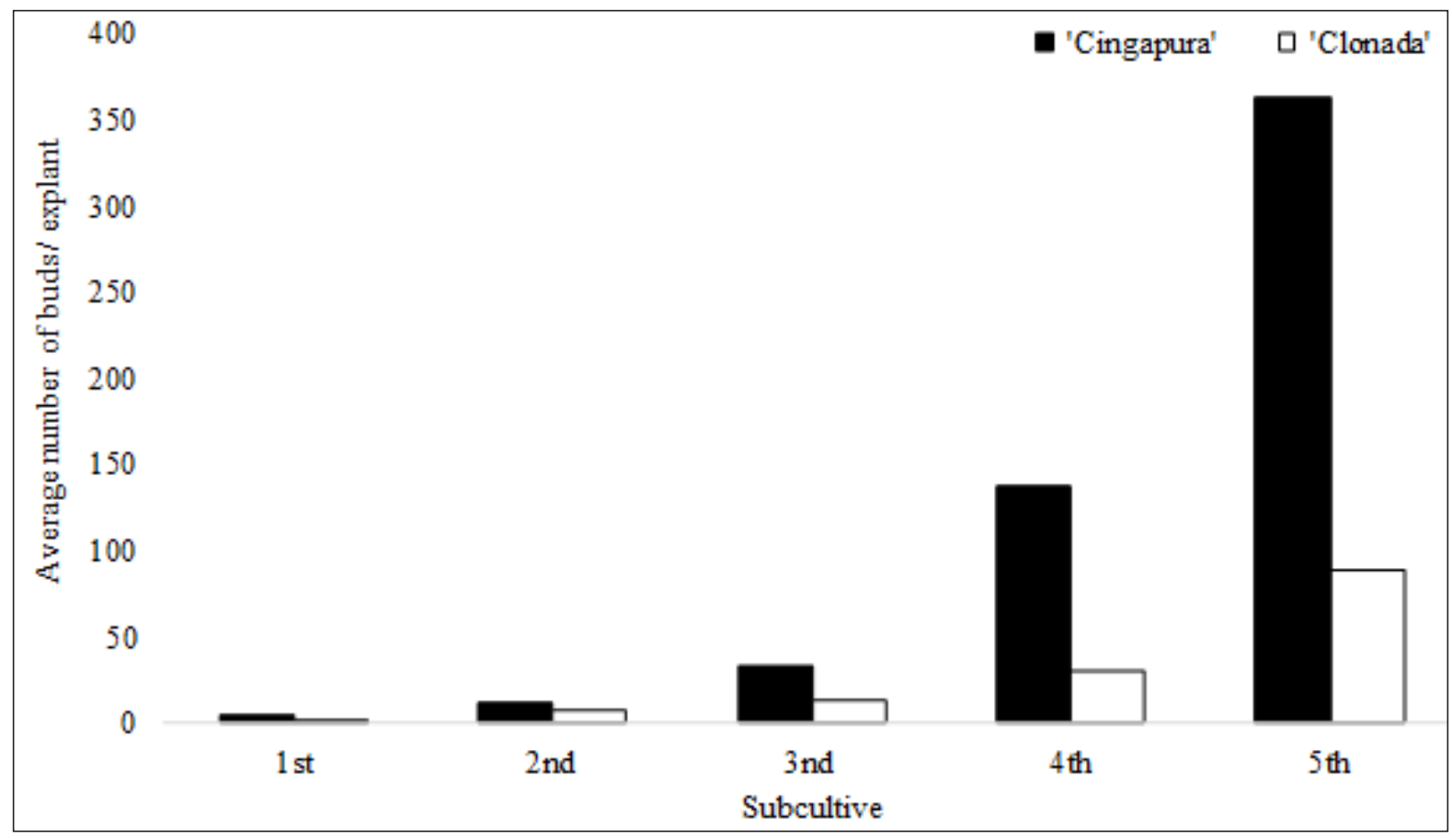

In vitro multiplication of black pepper is indicated for the mass propagation of the species, since the number of explants generated is high in relation to the initial phase, a desired factor when the aim is to propagate economically important species. Studies have shown that after 3-4 subcultures, it was possible to obtain average of 25 new buds (Philip et al., 1992).
The use of growth phytoregulators is important for in vitro propagation. BAP, a cytokinin, is considered an efficient phytoregulator in the in vitro multiplication phase of black pepper. When the species is cultivated in the presence of different phytoregulators (kinetin and BAP), BAP proved to be more competent for the proliferation of buds (Ahmad 
et al., 2011; Moura et al. 2009). For the rooting phase, it was observed that in vitro rhizogenesis of black pepper buds under the effect of NAA is more efficient when compared to culture medium without growth regulator, as it induces thinner and secondary roots (Lemos, 2003; Huyen et al., 2014).
Variables number of roots and shoot dry matter did not present significant difference for the different genotypes. Variables root length and diameter, bud length, number of leaves and root dry mass showed significant difference among genotypes. As for the root length, bud length and number of leaves, 'Cingapura' genotype was superior to 'Clonada' genotype (Table 2).

Table 2. In vitro rooting of buds of two black pepper genotypes in MS culture medium with $0.05 \mathrm{mg} \cdot \mathrm{L}^{-1} \mathrm{NAA}$ after eight weeks of cultivation.

\begin{tabular}{c|ccccccc}
\hline Genotype & N. R. & C. R. & D. R. & C. B. & N. F. & M. S. R. & M.S.P.A. \\
\hline 'Cingapura' & $6.13 \mathrm{a}$ & $32.85 \mathrm{a}$ & $0.26 \mathrm{~b}$ & $20.13 \mathrm{a}$ & $3.20 \mathrm{a}$ & $5.50 \mathrm{~b}$ & $35.81 \mathrm{a}$ \\
'Clonada' & $6.40 \mathrm{a}$ & $24.40 \mathrm{~b}$ & $0.40 \mathrm{a}$ & $15.34 \mathrm{~b}$ & $1.87 \mathrm{~b}$ & $17.10 \mathrm{a}$ & $29.50 \mathrm{a}$ \\
\hline \multicolumn{1}{c}{ CV $(\%)$} & 17.04 & 26.84 & 24.09 & 22.31 & 19.96 & 25.08 & 20.2 \\
\hline
\end{tabular}

N.R .: number of roots; C.R .: Root length in mm.; D.R: Root diameter in mm; C.B .: Bud length in mm; N.F .: Number of leaves in mm: M.S.R .: Root dry mass in mg; M.S.P.A .: Shoo dry mass in mg. Means followed by the same letter do not differ statistically from each other by the $\mathrm{F}$ test at $5 \%$ probability level.

Despite the greater number of leaves in 'Cingapura' genotype in relation to 'Clonada' genotype, small and narrow leaves with less leaf area are characteristics of the 'Cingapura' genotype, and this may explain the lower shoot dry mass accumulation (Lemos and Poltronieri, 2014). 'Cingapura' genotype was characterized by having roots of greater length, but of smaller diameter. Roots with this characteristic have already been observed in other studies with this genotype (Serrano et al., 2012).
The survival rate of explants in both genotypes was $80 \%$. In the acclimatization phase, considering number of roots and length, bud length and shoot dry mass, no significant difference was observed; however, for root dry mass and diameter and number of leaves, statistical difference among genotypes was observed. Responses regarding root dry mass and diameter followed the same pattern as in vitro rooting data, with 'Clonada' genotype being superior to 'Cingapura'. Regarding number of leaves, 'Cingapura' genotype was superior (Table 3).

Table 3. Acclimatization of two black pepper genotypes on vermiculite substrate after eight weeks.

\begin{tabular}{c|ccccccc}
\hline Genotype & N. R. & C. R. & D. R. & C. B. & N. F. & M. S. R. & M.S.P.A. \\
\hline 'Cingapura' & $7.44 \mathrm{a}$ & $44.57 \mathrm{a}$ & $0.16 \mathrm{~b}$ & $26.16 \mathrm{a}$ & $5.00 \mathrm{a}$ & $8.98 \mathrm{~b}$ & $56.21 \mathrm{a}$ \\
'Clonada' & $7.77 \mathrm{a}$ & $46.23 \mathrm{a}$ & $0.25 \mathrm{a}$ & $21.67 \mathrm{a}$ & $2.88 \mathrm{~b}$ & $26.18 \mathrm{a}$ & $60.40 \mathrm{a}$ \\
\hline CV (\%) & 17.92 & 23.41 & 36.61 & 30.83 & 20.91 & 22.45 & 25.24 \\
\hline
\end{tabular}

N.R .: number of roots; C.R .: Root length in mm.; D.R: Root diameter in mm; C.B .: Bud length in mm; N.F .: Number of leaves in mm: M.S.R .: Root dry mass in mg; M.S.P.A .: Shoo dry mass in mg. Means followed by the same letter do not differ statistically from each other by the $\mathrm{F}$ test at $5 \%$ probability level.

These results demonstrate that genotype influences species propagation and its induced morphological responses. According to the analyzed variable and its characteristics inherent to each genotype, responses are specific either in the in vitro multiplication phase (Castro et al., 2016) or via cutting in the conventional system (Serrano et al., 2012).

The behavior of the 'Cingapura' genotype in the acclimatization phase was the opposite of in vitro development, since the multiplication of explants and total formation of microplants were superior to the 'Clonada' genotype; however, 'Cingapura' did not continue with the same development pattern.

In this research, the environment in which plants remained was essential to achieve high survival rate in both genotypes, whose condition was relative humidity above $90 \%$. The conditions under study favored lower plant transpiration, indicating that the 
technique is viable for the propagation of black pepper mother plants, as high relative humidity is crucial for adequate plant development under the new condition (Hazarika, 2006).

One of the limiting steps in the in vitro plant propagation system is acclimatization, that is, the gradual adaptation of propagules when transferred from in vitro conditions to ex vitro conditions (Carvalho et al., 2011). In this stage, the plant goes from a condition of reduced transpiration flow and high nutrient availability, to an environment that demands increased transpiration rate and salt absorption (Hazarika, 2006).

It was possible to identify genotypes free from PYMoV virus, of which 'Cingapura' and 'Clonada' are of great commercial interest to pepper producers, therefore selected for the micropropagation stage. In vitro cultivation is a viable alternative for the propagation of PYMoV virus-free mother plants on a large scale.

\section{ACKNOWLEDGMENTS}

To Embrapa, Banco da Amazônia and Laboratory of Biotechnology of "Embrapa Amazônia Oriental" for the opportunity to develop research activities and CAPES for the scholarship.

\section{REFERENCES}

Ahmad, N.; Guo, B.; Fazal, H.; Abbasi, B. H.; Liu, C. Z.; Mahmood, T., Shinwari, Z. K. Feasible plantregeneration in black pepper from petiole explants. Journal of Medicinal Plants Research. 2011, 5, 4590-4595.

Boari, A. de J. Evaluation of the active germplasm bank of consumption-kingdom for virosis and development of a control strategy. Embrapa Amazônia OrientalDocumentos (INFOTECA-E), 2008. (in portuguese)

Bhat, A. I.; Biju, C. N.; Srinivasan, V.; Krishnamurthy, S. A. K. Current status of viral diseases affecting black pepper and cardamom. Journal of Spices and Aromatic Crops, 2018, 27, 1-16.

Bhat, A. I.; Devasahayam; S.; Sarma; Y. R.; Pant, R. P. Association of a badnavirus in black pepper (Piper nigrum L.) transmitted by mealybug (Ferrisia virgata) in India. Current science, 2003, 1547-1550.
Bhat, A. I.; Siljo,A.; Jiby, M. V.; Thankamani, C. K.; Mathew, P. A. Polymerase chain reaction (PCR) based indexing of black pepper (Piper nigrum L.) plants against Piper yellow mottle virus. Journal of Spices and Aromatic Crops, 2009, 18, 28-32.

Carvalho, A. C. P. P.; Torres, A. C.; Braga, E. J. B.; De Lemos, E. E. P.; Souza, F. V. D.; Peters, J. A.; Câmara, T. R. Plant tissue culture glossary. Plant Cell Culture \& Micropropagation, 2016, 7, 1, 30-60. (in portuguese)

Castro, G. L. S.; De Lemos, O. F.; Tremacoldi, C. R.; Moraes, F. K. C.; Dos Santos, L. R. R.; Pinheiro, H. A. Susceptibility of in vitro black pepper plant to the filtrate from a Fusarium solani f. sp. piperis culture. Plant Cell, Tissue and Organ Culture (PCTOC). 2016, 127, 263-268.

CONAB - Companhia Nacional de Abastecimento Precos. Disponíveis em: http://sisdep.conab.gov.br/ precosiagroweb/. 27/11/2018.

Duarte, M. De L.R.; Albuquerque, F.C. De; Poltronieri, L.S.; Trindade, D.R.; Kitajima, E.W.; Brioso, P.S.T. Yellow black pepper mottled. Embrapa Amazônia Oriental. Belém: Pará, 2000; Documentos, 62, 20p. (in portuguese)

Gibbs, A.; Mackenzie, A. A primer pair for amplifying part of the genome of all potyvirids by RT-PCR. Journal of virology methods, 1997, 63, 9-16.

HAZARIKA, B. N. Morpho-physiological disorders in in vitro culture of plants. Scientia horticulturae, 2006, 108, 2, 105-120.

Huyen, D. A.; Du, T. X.; Giap, D. D.; Ton, N. T. Preliminary study on the micropropagation in vitro of black pepper (Piper nigrum L.). Tap Chi Sinh Hoc, 2014, 27, 39-45.

Instituto Brasileiro de Geografia e Estatística - IBGE. Sistema de recuperação automática - SIDRA. 2016. Disponível em: http://www.sidra.ibge.gov.br/bda/ tabela/listabl.asp?c=1613\&z=p\&o=27. Acesso em: 26 de julho de 2019.

LEMOS, O. F. de. In vitro mutagenesis in the genetic improvement of black pepper (Piper nigrum L.). Tese de doutorado. Piracicaba - Escola Superior de Agricultura "Luiz de Queiroz", Universidade de São Paulo. 2003. 191p. (in portuguese) 
Lemos. O. F.; Poltronieri. M. C.; Rodrigues. S. De M.; Meneses. I. C. De; Mondin. M. Conservation and genetic improvement of black pepper (Piper nigrum L.) associated with biotechnology techniques. Embrapa Amazônia Oriental. Belém: Pará, 2011; Documentos, $375,45 p$. (in portuguese)

Lemos, O. F.; Poltonieri, M. C. Seedling productio. In.: Lemos, O. F.; Tremacoldi, C. R.; Poltonieri, M. C (ed.). Good agricultural practices for increasing productivity and quality of black pepper in the state of Pará. Belém: Embrapa Amazônia Oriental, 2014. 52 p. (in portuguese)

Lourinho, M. P.; Costa, C. A. S Da; Souza, L. C. De; Souza, L. C. De; Oliveira Neto, C. F. de. Conjuncture of black pepper in the national market and in the northern region of Brazil. Enciclopédia Biosfera. Centro Científico Conhecer, 2014, 10, 1016-1031. (in portuguese)

Lockhart, B. E. L.; Kiratiya-Angul, K.; Jones, P.; Eng, L.; Silva, P.; Olszewski, N. E.; Lockhart, N.; Deema, N.; Sangalang, J. Identification of Piper yellow mottle virus, a mealybug-transmitted badnavirus infecting Piper spp. in Southeast Asia. European Journal of Plant Pathology, 1997, 103, 303-311.

Miftakhurohmah, N. F. N.; Mariana, Maya; Wahyuno, Dono. Deteksi Piper Yellow Mottle Virus (PYMOV) penyebab penyakit kerdil pada tanaman lada secara Polymerase Chain Reaction (PCR). Buletin Penelitian Tanaman Rempah dan Obat, 2016, 27, 77-84.

Moura, E. F.; Menezes, I. C.; Lemos, O. F. Micropropagation of black pepper (Piper nigrum). Plant Cell Culture \& Micropropagation, 2009, 65-70.
Murashige, T.; Skoog, F. A revised medium for rapid growth and bioassays with tobacco tissue culture. Physiologia Plantarum, 1962, 15, 473-497.

Philip, V. J.; Joseph, D.; Triggs; G. S.; Dickinson, N. M. Micropropagation of black pepper (Piper nigrum L.) through shoot tip cultures. Plant Cell Reports, 1992, 12, 42-44.

Sasi, Shina; Bhat, A. I. In vitro elimination of Piper yellow mottle virus from infected black pepper through somatic embryogenesis and meristem-tip culture. Crop Protection, 2018, 103, 39-45.

Serrano, L. A. L.; Marinato, F. A.; Magiero, M., Sturm, G. M. Production of black pepper seedlings in commercial substrate fertilized with slow release fertilizer. Revista Ceres, 2012, 59, 512-517. (in Portuguese)

Silva, D. P. P.; Jones, P.; Shaw, M. W. Identification and transmission of Piper yellow mottle virus and Cucumber mosaic virus infecting black pepper (Piper nigrum) in Sri Lanka. Plant Pathology, 2002, 51, 537-545.

Umadevi, P.; Bhat, A. I.; Krishnamurthy, K. S.;Anandaraj, $M$. Influence of temperature on symptom expression, detection of host factors in virus infected Piper nigrum L. Indian journal of experimental biology, 2016, 54, 5, 354-360.

Umadevi, P.; Saji, K. V.; Suraby, E. J. Meristem culture for rapid regeneration in Black pepper (Piper nigrum Linn.). Annals of Plant Sciences, 2015, 4, 1029-1032. 